\title{
Formulasi Kebijakan Pembangunan Di Desa Dermaji Kecamatan Lumbir Kabupaten Banyumas
}

\author{
Chamid Sutikno $^{1 *}$, Shadu Satwika Wijaya ${ }^{1}$, Andi Zaelani ${ }^{2}$ \\ ${ }^{1}$ Dosen Program Studi Administrasi Publik, Universitas Nahdlatul Ulama Purwokerto, Indonesia \\ ${ }^{2}$ Mahasiswa Program Studi Administrasi Publik, Universitas Nahdlatul Ulama Purwokerto, Indonesia \\ Email: c.sutikno@unupurwokerto.ac.id
}

\begin{abstract}
Abstrak
Penelitian ini bertujuan untuk mengetahui formulasi kebijakan pembangunan di Desa Dermaji Kecamatan Lumbir, Kabupaten Banyumas. Dengan adanya kebijakan otonomi desa memberikan peluang bagi pemerintah desa dalam merencanakan pembangunan sesuai dengan kebutuhan masyarakat yang didasarkan pada pendekatan pertisipatif dan berkelanjutan. Tujuan Penelitian adalah untuk mengetahui (1) Proses penyusunan kebijakan pembangunan di Desa Dermaji. (2) Mengidentifikasi faktor yang menetukan penyusunan kebijakan pembangunan di Desa Dermaji sehingga dapat memperoleh berbagai bentuk penghargaan prestasi pembangunan. Penelitian ini dilakukan dengan menggunakan metode kualitatif, dengan pendekatan studi kasus. Teknik pemilihan informan menggunakan teknik purposive sampling. Teknik analisis data menggunakan model analisis interaktif. Sedangkan validitas data menggunakan pedekatan triangulasi untuk memperoleh data secara valid. Hasil penelitian menunjukan prose formulasi kebijakan yang meliputi aspek konseptualisasi masalah dan peranan kepemimpinan. Pengembangan opsi alternatif dalam proses pembangunan di Desa Dermaji dengan pendekatan partisipatif serta memadukan model elit dalam pengambilan keputusan sebagai pilihan alternatif kebijakan dan model partisipasi masyarakat pada keseluruhan tahapan pelaksanaan kebijakan melalui social collaborative action.

Kata Kunci: Fomulasi Kebijakan, Pembangunan Desa, Kepemimpinan.
\end{abstract}

\section{PENDAHULUAN}

Proses formulasi kebijakan dalam pembangunan desa adalah keseluruhan kegiatan yang meliputi perencanaan, pelaksanaan, penatausahaan, pelaporan, dan penentuan berbagai alternatif dan pilihan dalam upaya membangun keberlanjutan pembangunan ditingkat desa. (Abady, 2013). Formulasi kebijakan publik itu merupakan suatu proses yang memiliki peranan penting dalam pengambilan kebijakan publik (Abdul Rahman, Martoyo, 2016). Terdapat dua aspek yang harus diperhatikan dalam proses penyusunan kebijakan yaitu aspek elit dan pluralis. Dalam perspektif elit, proses perancangan agenda kebijakan diasumsikan tentang keberadaan elit pemerintah sebagai pemegang otoritas dan memiliki dominasi terhadap kelompok lain terhadap keputusan (Fandaru, 2016; Wu, Ramesj, Howlett, 2010). Argumentasi ini didasarkan pada posisi elit yang cenderung memiliki kekuasaan lebih besar dibandingkan masyarakat atau kelompok pada umumnya. Sehingga pelaksanaan agenda kebijakan hanya mampu di akses oleh kelompok kelompok tertuntu yang memiliki pengaruh kuat dalam sistem pemerintahan. Dalam perspektif elit ini akan sangat terliahat kelompok yang kuat dan kelompok yang tidak kuat dalam memasuki debat mengenai kebijakan, selain itu pada proses ini menekankan pada komunikasi politik antar lembaga pemerintah, media, dan kelompok 
yang terlibat dari masalah yang terpusat (Wu, Ramesj, Howlett, 2010). Kelemahan dari padangan elit ini melihat kekuasaan dan kepentingan hanya terletak pada monopoli pemerintah, dan mengabaikan adanya peranan kelompok lain sehingga kebijakan yang dilaksanakan hanya berjalan satu pikiran yang sama (Wu, Ramesj, Howlett, 2010).

Selanjutnya, dalam perspektif pluralis memberikan pandangan bahwa kelompok kepentingan dalam masyarakat menjadi pihak yang mendominasi dalam (Baekgaard et al., 2018). Proses agenda setting dianggap sebagai hasil dari reaksi atas aktivitas yang dilakukan oleh kelompok kepentingan dalam masyarakat. Kelompok kepentingan tersebut mengidentifikasi masalah kemudian ditetapkan pada pemerintah agar menjadi agenda (Baekgaard et al., 2018). Kelompok kepentingan tersebut bisa melakukan tekanan terhadap pemerintah untuk menolak isu-isu kebijakan yang sudah di agendakan. Interfensi politik mempengaruhi proses kebijakan yang juga memberikan perspektif komparasi baru yang berbeda dengan kelembagaan struktural. Ini adalah merupakan dinamika kelompok yang saling berkoalisi dan bergabung menjadi kekuatan menjadi upaya advokasi. Koalisi advokasi merupakan tahapan dari persatuan dari kelompok-kelompok yang memiliki keyakinan bersama tentang isu atau masalah tertentu. Proses pembuatan kebijakan merupakan proses dilaksanakan agar penentuan kebijakan sesuai dengan yang diharapkan, pendekatan dalam mengkaji kebijakan publik agar mudah dipahami. Model dalam kebijakan publik memberikan representasi mengai aspek-aspek untuk menemukan tujuan tertentu. Pemilihan model dalam kebijakan publik menjadi salah satu metode dalam menyederhanakan suatu kompleksitas permasalahan untuk menjadi sesuatu yang lebih mudah untuk dipahami dan di analisis dalam proses kebijakan publik. Model kebijakan menjadi pola hubungan yang menjadi pedoman dalam menentukan konsep-konsep gejala sosial yang saling berkaitan (Nugroho, 2008).

Model kebijakan publik yang dikembangkan oleh para ahli kebijakan publik. Di mana, salah satu ahli yang akan dibahas dalam tulisan ini adalah model kebijakan publik yang dikembangkan oleh Thomas R. Dye. Model kebijakan publik menurut Thomas R. Dye (1978) meliputi beberapa aspek yang menjadi landasan dalam pengambilan kebijakan. (Nugroho, 2008; Rahman et al., 2014). Pendekatan pluralis dalam formulasi kebijakan merupakan dinamika kelompok dalam membangun kekuatan penyeimbang dengan para elit penguasa dan berusaha mempengaruhi proses pembuatan kebijakan. Kondisi ini dilakukan agar setiap isu yang dibawa mampu mendaptkan perhatian dan tempat yang menguntungkan. Di mana, kelompok-kelompok ini memiliki tempat pada kelembagaan pemerintah (Rothstein \& Valletta, 2017). Dominannya peran elite dalam proses penyusunan kebijakan pembangunan tanpa melibatkan peran aktif masyarakat dalam keseluruhan tahapan proses penyusunan kebijakan pembangunan akan menyebabkan sebuah kebijakan yang tidak berpihak kepada masyarakat. 
Penguasaan elit atas pembangunan yang berpola desentralisasi juga rentan terjadi ketika kekuatan sosial tidak dilibatkan (Simonet, 2018).

Salah satu formulasi kebijakan mengenai pembangunan desa menjadi sangat penting untuk dikaji. Dimana saat ini desa menjadi leading sektor dalam pembangunan nasional. Desa sebagai embrio dalam pembangunan nasional menjadi titik penting untuk meningkatkan kulitas dan daya saing dalam upaya pemberdayaan masyrakat. Adanya pembangunan desa yang sinergis akan mampu mendorong kesejahteraan masyarakat (Dewanta, 2004; Yudartha \& Winaya, 2018). Undang-undang No. 6 Tahun 2014 tentang desa mengatur mengenai kewenangan desa dan alokasi dana desa yang pasti untuk mendorong pembangunan desa. Musyawarah desa menjadi wahana untuk membahas hal-hal strategis desa termasuk perencanaan pembangunan desa yang menekankan pentingnya partisipasi seluruh unsur masyarakat desa (Dewanta, 2004).

Desa Dermaji merupakan salah satu desa yang berada di Kecamatan Lumbir Kabupaten Banyumas, dimana saat ini desa lumbir menjadi salah satu desa yang mampu membuktikan dalam upaya peningkatan kapasitas pembangunan desa. Saat ini desa dermaji menjadi salah satu desa yang memiliki laju peningkatan pembangunan yang relatif tinggi dan menjadi rujukan bagi desa-desa yang ada di sekitar Kabupaten Banyumas. Dalam menunjang keberhasilan pembangunan desa tentunya tidak lepas dari proses perumusan kebijakan yang menjadi landasan dalam pelaksanaan kegiatan pembangunan desa. Pembangunan di Desa Dermaji saat ini tentunya tidak lepas dari upaya dan kerjasama dan colaborasi lintas stakeholders dalam mecapai tujuan pembangunan dan pemberdayaan masyarakat yang adil dan berkelanjutan. Komitmen Desa Dermaji yang terus menerus berjuang menuju kemandirian melalui tata kelola sumber daya desa secara optimal dan peningkatan pelayanan publik yang mampu membawa Dermaji menjadi desa yang sukses dalam berbagai capaian pembangunan. Berbagai prestasi yang diraih oleh Desa Dermaji baik ditingkat lokla dan nasional menjadi acuan dalam peningkatan pembangunan untuk meningkatkan akses perekonomian dan pemberdayaan masyarakat setempat. Melihat hal tersebut penelitian ini mencaoba menganalisis proses dan bagaimana model dalam penyusunan kebijakan pembangunan desa serta faktor-faktor yang menentukan proses penyusunan kebijakan pembangunan Desa Dermaji. Hal yang menjadi sangat penting dalam tahapan pembuatan kebijakan pembangunan di Desa Dermaji adalah parisipasi masyarakat dalam tahap formulasi kebijakan dalam perencanaan pembangunan yang selama ini sudah dilakukan oleh Desa Dermaji. 


\section{TINJAUAN PUSTAKA}

\section{Administrasi Publik Dan Kebijakan Publik}

Administrasi publik merupakan sebuah konsep yang sulit didefinisikan. Oleh karenanya Kernaghan (2010) menyatakan bahwa administrasi publik tidak memiliki definisi tunggal yang dapat diterima secara umum. Ruang lingkup subyek dan disiplin administrasi publik sangat luas dan selalu diperdebatkan, menyebabkan lebih mudah menjelaskan makna administrasi publik dari pada mendefinisikan. Sebagai upaya untuk menjernihkan posisi administrasi publik, Waldo (2013: 392 - 416) dan Vigoda (2003: 1 - 22) misalnya, menyebutkan bahwa administrasi publik merupakan bidang ilmu yang bersifat eclectic. Sifat eklektik (teori administrasi publik berasal dari berbagai bidang ilmu lain) ini pada akhirnya melahirkan pemahaman yang beragam tentang administrasi publik. Sifat eklektik ini dapat dilacak dari revolusi yang mengubah praktik administrasi publik menjadi sains dan profesi yang dipelopori oleh karya Woodrow Wilson (1887) dan Frank J. Goodnow (1900). Merekalah yang pertama kali mendorong otonomi keilmuan administrasi publik dengan mengadopsi berbagai teori yang terdapat dalam bidang ilmu hukum, politik, teknik, dan psikologi. Wilson (1887) memaknai administrasi publik sebagai pelaksanaan hukum atau kebijakan secara rinci dan sistematis. Oleh karenanya, setiap aktivitas pelaksanaan kebijakan dapat dimaknai sebagai tindakan administrasi publik. Melalui konsep yang sangat terkenal tentang dikotomi politikadministrasi, Wilson (1887) dan Goodnow (1900) menegaskan bahwa tugas utama politik adalah membuat kebijakan, sedangkan administrasi publik melaksanakan kebijakan. Pemahaman administrasi publik tersebut, mencerminkan pandangan bahwa aktivitas administrasi publik hanya terlibat dalam melaksanakan kebijakan dan program pemerintah. Administrasi publik tidak memiliki peran dalam pembuatan kebijakan. Melalui perjalanan waktu, makna administrasi publik terus berkembang sesuai dengan perkembangan teori dan praktik administrasi publik. Pada saat ini teori dan praktik administrasi publik juga mencakup pembuatan kebijakan, tidak hanya melaksanakan kebijakan. Bahkan administrasi publik pada saat ini ada yang memaknai sebagai governance (Frederickson, 1997; Peters \& Pierre, 1998; Kettl, 2000; Henry, 2013). Henry (2013) menyatakan bahwa administrasi publik adalah kombinasi yang luas dari teori dan praktik administrasi publik. Tujuannya untuk mempromosikan pemahaman yang unggul tentang pemerintah dan hubungannya dengan masyarakat, serta untuk mendorong kebijakan publik lebih responsif terhadap kebutuhan sosial dan untuk melembagakan praktik manajerial yang selaras dengan efektivitas, efisiensi, dan kebutuhan manusia sebagai warga negara. 


\section{Proses penyusunan Kebijakan Publik.}

Formulasi kebijakan publik merupakan salah satu tahapan dari kebijakan publik untuk mmemastikan berbagai perumusan dan penentuan arah alternatif yang akan dipilih dan dilaksanakan sebagai kebijakan publik (Rahman et al., 2014). Formulasi kebijakan merupakan tahapan yang sangat penting dari proses pembuatan kebijakan dari tahap pra-pengambilan keputusan termasuk menyusun tujuan dan prioritas dan pilihan, biaya dan manfaat dari setiap pilihan, eksternalitas dari setiap pilihan melibatkan mengidentifikasi seperangkat alternatif kebijakan dan alat kebijakan publik dalam mengatasi masalah yang disiapkan untuk solusi akhir yang benar-benar dipilih oleh pembuat keputusan. Perumusan (formulasi) kebijakan merupakan tahapan yang sangat penting dalam sebuah siklus kebijakan publik (Wu, et al. 2010: 47). Formulasi kebijakan adalah aktivitas untuk mengembangkan alternatif, proposal, atau opsi kebijakan untuk menangani masalah publik yang telah ditetapkan dalam penyusunan agenda pemerintah (Dye, 2013: 42; Anderson, 2003: 101). Kebijakan publik ini lahir dari upaya masyarakat untuk mempengaruhi perubahan perilaku kelembagaan atau publik mereka sendiri. Khususnya untuk mencapai beberapa tujuan akhir yang oleh para pelaku kebijakan utama dianggap penting. Kebijakan publik ini ditetapkan oleh pemerintah, tetapi penyusunannya melibatkan interaksi yang amta kompleks dari aktor dan lembaga lain, baik swasta, bisnis, kelompok masyarakat, dan institusi lainnya (Howlett \& Ramesh, 2016). Perumusan kebijakan adalah bagian dari proses pengembangan kebijakan publik, yang melibatkan pemerintah dan aktor kebijakan lainnya, untuk bertanya dan menjawab pertanyaan tentang bagaimana masyarakat dapat menangani berbagai macam masalah dan kondisi yang mempengaruhi kehidupan masyarakat dan organisasi dalam mencapai tujuan mereka. Solusi apa pun yang muncul dari kegiatan formulasi kebijakan adalah dasar adopsi dan penetapan kebijakan publik. Dengan demikian tahap formulasi kebijakan berkaitan dengan upaya menentukan pilihan tindakan, guna mengatasi masalah publik (Howlett, 2011: 29).

Kegiatan formulasi kebijakan tidak hanya mencakup penghitungan manfaat dan risiko relatif dari berbagai opsi kebijakan yang dapat dianggap cocok dengan sasaran kebijakan yang ditetapkan, tetapi juga menyangkut kelayakan atau penerimaan terhadap opsi tersebut. Pada tahap formulasi kebijakan ini, unsur-unsur teknis maupun politis menjadi pertimbangan penting dalam menetapkan solusi kebijakan (Howlett dan Mukherje, 2003). Anderson (2003: 101 - 102) menjelaskan bahwa pada tahap formulasi kebijakan, para pembuat kebijakan dihadapkan dengan beberapa proposal yang biasanya saling bersaing untuk dipilih dalam menangani masalah. Bahkan para pembuat kebijakan mungkin juga harus bekerja kerasuntuk merancang alternatif solusi yang mereka buat sendiri. Formulasi kebijakan tidak selalu harus berujung pada peraturan hukum atau pemerintah. Artinya, hanya karena masalah telah 
mencapai agenda pemerintah atau agenda kebijakan, tidak berarti tindakan positif akan diambil. Selama formulasi kebijakan, pembuat kebijakan dapat memutuskan untuk mengusulkan apa pun atau dapat tidak menyetujui apapun yang dapat dilakukan.

\section{METODE PENELITIAN}

Penelitian ini dilakukan menggunakan pendekatan kualitatif (Ashworth et al., 2019; Brower et al., 2000; Ospina et al., 2018a). Penelitian ini menggunakan pendekatan studi kasus dalam penyusunan kebijakan pembangunan di Desa Dermaji (Shiddike \& Rahman, 2020). Pengumpulan data dalam penelitian ini, dilakukan dengan wawancara mendalam, observasi dan dokumentasi (Morgan, 2017). Dalam penelitian ini terkait dengan pemilihan informan dilakukan dengan teknik purposive sampling (Hektner et al., 2012; Nathan \& Scobell, 2012). Analisis data yang digunakan dengan analisis interaktif(B.Miles et al., 2014) dengan desain deskriptif untuk menganalisis tujuan penelitian pertama dan desain eksplanatori untuk menganalisis tujuan penelitian kedua (Creswell \& Creswell, 2018a; Wisdom \& Creswell, 2013). Sasaran pada penelitian ini terdiri dari unsur pemerintah desa, BPD, Tokoh masyarakat dan para stakeholder yang terlibat dalam penyusunan perencanaan kebijakan pembangunan di Desa Dermaji. Para informan yang dipilih dilakukan secara purposive sampling agar sesuai dengan tujuan penelitian (Creswell \& Creswell, 2018b; Tashakkori \& Newman, 2010). Validitas datan penelitian ini menggunakan metode trianggulasi data sumber dan dokumen (Creswell \& Creswell, 2018a).

\section{HASIL DAN PEMBAHASAN}

Kebijakan Publik adalah suatu keputusan yang dimaksudkan untuk mengatasi persoalan yang muncul dalam kegiatan tertentu yang dilakukan oleh instansi pemerintah sebagai penyelenggaraan pemerintahan yang kondusif, aspiratif, dan demokratis (Kadji, 2015). Terdapat beberapa hal yang terkandung dalam kebijakan, yaitu:

1. Kebijakan Pembangunan mempunyai tujuan yang ingin dicapai, tujuan tertentu adalah tujuan yang berpihak kepada kepentingan masyarakat (Suwitri, 2014) . Seperti halnya kebijakan pembangunan di Desa Dermaji sudah diformulasikan dan direncanakan sangat baik sehingga dapat menghantarkan Desa Dermaji mencapai tujuan yang sudah ditetapkan dalam perencanaan pembangunan dibuktikan dengan dokumen RPJMDes dan RKPDes yang banyak sekali memuat usulan-usulan dan program pemberdayaan perencanaan pembangunan yang akan dilaksanakan di Desa Dermaji;

2. Serangkaian tindakan untuk mencapai tujuan. Serangkaian tindakan untuk mencapai tujuan adalah strategi yang disusun untuk mencapai tujuan dengan lebih mudah yang acapkali dijabarkan ke dalam bentuk program dan proyek-proyek Pembangunan Desa Dermaji telah tersusun dan terdokumentasikan sangat baik di dalam dokumen Rencanaan 
Pembangunan Jangka Menengah Desa (RPJMDes) yang kemudian akan dijabarkan ke dalam Rencara Kerja Pemerintah Desa (RKPDes) hal ini dapat dibuktikan dengan dokumen RPJMDes Desa Dermaji Tahun 2019-2024 dan Peraturan Desa Dermaji tentang Anggaran Pendapatan dan Belanja Desa Tahun Anggaran 2021;

3. Usulan tindakan dapat berasal dari perseorangan atau kelompok dari dalam ataupun luar pemerintahan. Proses penyusunan rencana pembangunan di Desa Dermaji dilakukan dengan mengikuti aturan regulasi yang sudah ditentukan, yaitu melalui mekanisme penjaringan aspirasi masyarakat sebagai usulan yang harus dijadikan rencana setrategis dan bentuk partisipasi publik dalam tahapan formulasi perencanaan program-program pembangunan. Namun apabila hanya melalui usulan masyarakat program pembangunan menjadi tidak inovatif dikarenakan usulan masyarakat lebih pada pembangunan insfrastruktur. Hasil penelitian memnunjukan bahwa yang dilakukan dalam formulasi kebijakan pembangunan Desa Dermaji adalah ada yang melalui formal dan informal. Penjaringan aspirasi yang informal melalui bertanya langsung terhadap masyarakat. sementara yang formal mulai forum-forum dari musyawarah tingkat komunitas, musyawarah dusun, lokakarya desa, sampai dengan musyawarah rencana pembangunan desa dan forum yang disaratkan oleh regulasi yaitu musyawarah di tingkat dusun (Musdus) dan musyawarah desa (Musdes). Setelah terkumpul data-data terkait usulan masyarakat selajtnya dilakukan inovasi melalui kelompok-kelompok musyawarah khusus (Mushus) seperti di bidang kesehatan, musyawarah khusus perempuan, bidang pendidikan, peternakan dan pertanian, dan kepemudaan. Harapannya adalah agar dari semua kelompok muncul ide-ide atau gagasan dan harapan kelompok tersebut dapat dibaca dan direalisasikan;

4. Penyediaan input untuk melaksanakan strategi. Input berupa sumberdaya baik manusia maupun bukan manusia.

Dalam pelaksanaan kebijakan pembangunan, sumberdaya merupakan aspek penting sebagai faktor keberhasilan. Sumberdaya meliputi sumberdaya manusia dan sumberdaya non manusia. Sumber daya manusia sangat diperlukan oleh karena manusia merupakan agen perubahan yang akan membawa dari kondisi yang tidak dikehendaki menuju kondisi yang dikehendaki. Sumber daya non manusia merupakan aspek penunjang pada pelaksanaan kebijakan. Dalam proses pelaksanaan kebijakan sumberdaya manusia yang berkualitas sangat dibutuhkan mulai dari proses formulasi sampai dengan proses evaluasi sebuah kebijakan. Seperti hasil penelitian untuk melaksanakan program-program kebijakan yang sudah ditetapkan diperlukan sumberdaya manusia yang kompeten maka diselenggarakan upaya peningkatan sumberdaya manusia nelalui berbagai macam usaha yang dilakukan. Hal ini dikuatkan dengan hasil wawancara dengan Kepala Urusan Perencanaan Desa Dermaji bahwa dalam proses perumusan 
program-program itu, SDM sudah dibicarakan baik SDM pelaksanan maupun SDM pendukung. Jika SDM yang ada dirasa kurang maka dilakukan langkah-langkah misalnya harus ada pelatihan, bimtek dan proses pendampingan secara berkelanjutan.

\section{Proses penyusunan Kebijakan Pembangunan Di Desa Dermaji}

Penyusunan atau formulasi kebijakan publik merupakan salah satu tahapan yang sangat penting dari rangkaian proses pembuatan dan pelaksanaan suatu kebijakan publik. Penentuan pemilihan alternatif untuk ditetapkan menjadi sebuah kebijakan dalam rangka untuk memecahkan masalah (Rahman et al., 2014). Proses tersebut meliputi dua elemen dasar, yaitu partisipasi masyarakat dan bantuan pelayanan teknis dari pemerintah. Proses tersebut diwujudkan dalam berbagai program yang dirancang untuk kepentingan masyarakat (Nugroho, 2008). Berdasarkan penelitian hal ini telah dilakukan di Desa Dermaji. Hasil penelitian ini menjelaskan bagaimana kepala desa mampu melibatkan semua unsur masyarakat dalam setiap proses pengambilan kebijakan. Proses perumusan kebijakan yang dilakukan pada dasarnya secara teknis sama seperti aturan yang sudah ada, dimana pelibatan masyarakat berbasis aspirasi mulai dari rapat RT, rapat dusun, rapat desa sampai tahapan musrembang. Tetapi yang paling penting dalam proses penjaringan aspirasi bukan hanya pada sekedar formalitas tetapi adanya pendampingan program yang manjadi usulan masyarakat. Artinya disini proses komunikasi dan advokasi kebijakan pembangunan desa mampu dilaksanakan dengan baik.

Dalam proses perumusan kebijakan secara garis besar meliputi beberapa aspek yang perlu diperhatikan untuk mencapai kesepakatan dan kesamaan presepsi baik dari pemerintah Desa Dermaji dan masyarakat.

1. Identifikasi Masalah pembangunan desa, dalam perumusan kebijakan pembangunan Desa Dermaji tidak lepas dari tahapan identifikasi maslah. Adanya pemetaan yang meliputi kondisi sosial ekonomi masyarakat, identifikasi kondisi geografis, indentifikasi sumberdaya perangkat desa, serta identifikasi peluang dan potensi ekonomi desa yang meliputi aspek mata pencaharian masyarakat Desa Dermaji. Setelah identifikasi masalah yang dilakukan oleh pihak pemerintah desa, maka ditemukan skala prioritas dalam tahapan pembangunan. Secara garis besar kondisi gografis desa dermaji yang berada di tengah-tengah wilayah pengunungan menjadi prioritas pembagunan infrastruktur menjadi hal yang utama. Selanjutnya identifikasi ekonomi masyarakat sehingga pilihan alternatif pemberdayaan masyarakat yang di ambil dengan pembentukan BUMDes, kelompok usaha, kelompok peternak, dan kelompok penyadap getah pinus, serta pengembangan sektor pertanian. Hal ini dilakukan secara bertahap dengan pembuatan 
road map pembangunan Desa Dermaji yang secara bertahap terus dilakukan oleh pemerintah desa;

2. Proses Pengembangan Opsi Alternatif Kebijakan, pengembangan opsi alternatif kebijakan pembangunan desa dilakukan dengan model delibertive dan kooprative yang dilakukan oleh pemerintah Desa Dermaji. Pengembangan opsi alternatif di dasarkan pada ketentuan kebutuhan masyarakat yang meliputi kebutuhan dasar, dimana adanya pemetaan masalah dan potensi desa;

3. Hasil Musyawarah dan Konsultasi dalam Penentuan Solusi Alternatif, dalam aspek ini semua usulan dan aspirasi dari masyarakat ditinjau ulang dan dilakukan review terkait dengan pelaksanaan pembangunan desa. Dimana pelibatan unsur masyarakat menjadi prioritas dalam mencari dan menetukan solusi permasalahan yang dihadapi. Sehingga kebijakan yang kita lakukan berdasar pada kebutuhan masyarakat bukan keinginan pemerintah semata.

\section{Konseptualisasi Masalah Dan Karakter Kepemimpinan Dalam Formulasi Kebijakan Pembangunan Di Desa Dermaji}

Salah satu cara paling mudah untuk memahami proses perumusan kebijakan adalah dengan memecahnya menjadi beberapa tahapan atau komponen. Wolman (1981) menyebutkan, formulasi kebijakan terdiri dari beberapa komponen, yang masing-masing memengaruhi kinerja kebijakan secara keseluruhan. Pada tahap pertama, proses perumusan dimulai dengan konseptualisasi masalah oleh pembuat kebijakan. Pada tahap ini, masalah yang telah ditetapkan diidentifikasi oleh para pemangku kepentingan guna menemukan akar masalah yang sesungguhnya. Konseptualisasi masalah menjadi tahapan yang sangat penting, karena akan menentukan keberhasilan perumusan kebijakan pada tahap berikutnya (Wolman, 1981: 435; Thomas, 2001: 216 - 217). Setelah menetapkan keberadaan masalah kebijakan melalui beberapa bentuk pengumpulan data, pada tahap kedua, berbagai dimensi kebijakan yang relevan dari masalah tersebut kemudian dievaluasi untuk menentukan penyebab dan luasnya masalah. Dimensi kebijakan menyangkut berbagai aspek, baik sosial, ekonomi, politik, maupun aspek khusus terkait dengan masalah yang dibahas. Hal ini dimaksudkan sebagai dasar untuk mengidentifikasi solusi kebijakan potensial dan sesuai dengan masalah kebijakan yang dihadapi (solusi alternatif kebijakan). Pemahaman yang tidak memadai pada tahap penetapan masalah ini, dapat berakibat kesalahan dalam menentukan solusi kebijakan. Oleh karenanya Wolman (1981: 437) menyatakan bahwa semakin baik pemahaman tentang proses sebab-akibat suatu masalah, maka semakin besar peluang keberhasilan untuk dapat menyusun kebijakan publik bagi penanganan masalah tersebut. 
Demikian pula $\mathrm{Wu}$, et al. (2010: 40) menyatakan bahwa memahami sumber masalah adalah bagian yang tidak dapat dihindari dari formulasi kebijakan. Untuk itu dalam formulasi kebijakan perlu mengenali karakterisasi masalah sejak awal serta mengevaluasi penyebab masalah tersebut. Ketika konsensus tentang sifat dan tingkatan masalah telah dicapai, para pembuat kebijakan beralih untuk mempertimbangkan tanggapan yang sesuai. Pada tahap ketiga ini, melalui pengumpulan informasi awal dan analisis sebab-sebab terkait masalah, selanjutnya dilakukan perumusan spesifikasi tujuan (Wolman 1981: 438) atau klarifikasi tujuan kebijakan (Wu, et al. 2010: 40) ditetapkannya kebijakan publik. Setelah tujuan kebijakan ditetapkan, selanjutnya dilakukan evaluasi terhadap opsi kebijakan spesifik guna mengembangkan rekomendasi kebijakan bagi desain kebijakan. Tahap ini merupakan tahap yang ke empat dari proses perumusan kebijakan. Perumusan kebijakan merupakan upaya "mengeksplorasi siapa yang terlibat dalam merumuskan kebijakan, bagaimana kebijakan itu dicapai, disepakati, dan bagaimana mereka saling berkomunikasi" (Buse, et al., 2012: 14). Tahap perumusan kebijakan merupakan komponen penting dari proses kebijakan, karena tahapan kebijakan selanjutnya akan tergantung pada isi kebijakan yang disepakati selama tahap perumusan kebijakan. Guna memahami proses perumusan (formulasi) kebijakan, Berlan et al. (2014) mengembangkan langkah-langkah perumusan kebijakan yang meliputi: 1) pembuatan alternatif kebijakan, 2) musyawarah dan/atau konsultasi, 3) advokasi untuk alternatif spesifik, 4) melobi untuk alternatif tertentu, 5) negosiasi alternatif kebijakan, 6) penyusunan atau diberlakukannya kebijakan dan 7) bimbingan/pengaruh pada implementasi. Berkaitan denga konseptualisasi masalah terkait dengan pembangunan Di Desa Dermaji dilakukan dengan beberapa tahapan yaitu:

1. Adanya pemetaan masalah dalam pembangunan dan potensi yang dilmiliki oleh Desa Dermaji

2. Penentuan upaya dan strategi pembangunan desa secara komperhensif dari berbagai aspek pembangunan baik pembangunan sumberdaya manusi dan pembangunan infrastruktur di Desa Dermaji

3. Adanya proses kolaborasi dari berbagai unsur dalam membangun kesamaan presepsi atas suatu masalah secara bersama baik Pemerintah Desa Dermaji dan masyarakat

4. Membangun jejaring aspirasi yang berupaya dalam mengakumulasi berbagai kepentingan masyarakat dalam perencanaan pembangunan di Desa Dermaji

Dalam proses formulasi kebijakan pembangunan Di Desa Dermaji tentunya tidak akan lepas dari adanya pengaruh kepemimpinan. Kepemimpinan tentunya akan memiliki kekuatan dalam memberikan arahan dan kontrol dalam penyelenggaraan pembangunan desa. Berdasarkan hasil penelitian dapat diketahui bahwa kepala Desa Dermaji memiliki kemampuan dan kapasiatas untuk mempengaruhi unsur pemerintahan desa dan masyarakat dalam 
pelaksanaan kebijakan pembangunan di Desa Dermaji. Hal ini disebabkan karena kemampuan Kepala Desa mengetahu secara langsung berbagai permasalahan yang di hadapi oleh masyarakat. Sehingga kebijakan yang dibuat berorientasi pada prioritas kebutuhan masyarakat baik dari sisi pembangunan infrastruktur, pemberdayaan masyarakat, peningkatan kualitas pendidikan masyarakat, serta pengembangan sektor-sektor ekonomi strategis yang dimiliki oleh Desa Dermaji. Kepemimpinan kepala desa yang sudah masuk periode ketiga ini menjadikan kemampuan kepala desa dalam mengidentifikasi dan pencarian solusi secara komperhensif. Kemampuan kepemimpinan kepala desa yang mampu membangun jejaring kebijakan dan colaborasi dengan berbagai pihak menjadikan Desa Dermaji memiliki akses dalam melakukan inovasi dan perubahan dalam peningkatan pembangunan desa. Kemitraan yang saat ini dibangun oleh Desa Dermaji dengan beberapa pihak perguruan tinggi yang ada di Kabupaten Banyumas sangat mendorong dalam upaya pemberdayaan masyarakat.

\section{Proses Pengembangan Opsi Alternatif Dalam Formulasi Kebijakan Pembangunan Di Desa Dermaji}

Howlett (2011: 31) mengatakan, bagian dari proses perumusan ini mencermati bagaimana pejabat publik mempertimbangkan bukti pada opsi kebijakan dan menyusun beberapa buah proposal guna mengidentifikasi opsi mana yang akan diajukan ke tahap ratifikasi atau penetapan opsi solusi yang paling tepat (tahap ke lima). Sebelum kebijakan ditetapkan secara final, kebijakan tersebut perlu menjalani desain langkah kelima. Di sini para perumus kebijakan melakukan berbagai pertimbangan terhadap berbagai instrumen kebijakan, baik yang bersifat internal maupun eksternal. Pada tahap ini menurut Wolman (1981: 440 - 446), pertimbangan yang digunakan biasanya menyangkut faktor kelayakan politik, 'kelayakan teknis, dan konsekuensi-konsekuensi yang kemungkinan muncul dari desain kebijakan yang dihasilkan. Kelima langkah tersebut, pada hakekatnya penuh dengan konflik. Salah satu cara untk menghilangkan konflik pada seluruh proses perumusan adalah dengan terlibat dalam apa yang disebut Thomas (2001: 218) pembangunan konsensus atau konsolidasi, di mana kesepakatan dicari antara berbagai formulator kebijakan dan kelompok kepentingan lainnya.

Anderson (2003: 101 - 102) menjelaskan bahwa pada tahap formulasi kebijakan, para pembuat kebijakan dihadapkan dengan beberapa proposal yang biasanya saling bersaing untuk dipilih dalam menangani masalah. Bahkan para pembuat kebijakan mungkin juga harus bekerja kerasuntuk merancang alternatif solusi yang mereka buat sendiri. Formulasi kebijakan tidak selalu harus berujung pada peraturan hukum atau pemerintah. Artinya, hanya karena masalah telah mencapai agenda pemerintah atau agenda kebijakan, tidak berarti tindakan 
positif akan diambil. Selama formulasi kebijakan, pembuat kebijakan dapat memutuskan untuk mengusulkan apa pun atau dapat tidak menyetujui apapun yang dapat dilakukan.

Formulasi kebijakan merupakan tahap pembuatan kebijakan di mana berbagai opsi yang tersedia dipertimbangkan dan kemudian dikurangi menjadi beberapa opsi yang relevan oleh para pelaku kebijakan, khususnya pemerintah. Kegiatan formulasi kebijakan tidak hanya mencakup penghitungan manfaat dan risiko relatif dari berbagai opsi kebijakan yang dapat dianggap cocok dengan sasaran kebijakan yang ditetapkan, tetapi juga menyangkut kelayakan atau penerimaan terhadap opsi tersebut. Pada tahap formulasi kebijakan ini, unsur-unsur teknis maupun politis menjadi pertimbangan penting dalam menetapkan solusi kebijakan (Howlett dan Mukherje, 2017). Dari hasil penelitian ini secara garis besar dapat diketahui mengenai aspek pengembangan opsi alternatif dalam formulasi kebijakan pembangunan Desa Dermaji dilakukan dengan beberapah langkah. Pertama opsi pembangunan dengan skala prioritas dimana opsi pembangunan dilakukan dengan adanya kebutuhan yang paling pokok. Kedua adanya opsi pembangunan dan pemberdayaan ekonomi masyarakat. Ketiga pengembangan opsi pembangunan sektor pertanian dan peternakan sebagai penggerak ekonomi masyarakat. Keempat pengembangan opsi pembangunan sektor pariwisata, yang mana masuk dalam rencana pembangunan desa, bahwa Desa Dermaji berupaya mengembangan potensi alam sebagai desa wisata. Dari berbagai opsi alternatif secara bertahap di realisasikan dan masuk dalam rencana pembangunan desa. Seluruh opsi altenatif dalam perumusan kebijakan pembangunan semua di inventarisir dan dilaksanakan secara bertahap. Artinya opsi-opsi yang mendukung perencanaan pembangunan desa dijadikan acuan dalam pembangunan secara berkelanjutan.

\section{Hasil Musyawarah dan Pendekatan Model Elit Dalam Formulasi Kebijakan Pembangunan Di Desa Dermaji}

Salah satu aspek yang dikaji dalam formulasi kebijakan pembangunan Desa Dermaji adalah berupaya untuk menganalisis sejauh mana pendekatan/model elit dalam pembambilan keputusan dilaksanakan. Pendekatan elit mencoba memberikan gambaran terkait pihak/aktor dalam proses pengambilan kebijakan (dalam hal ini pemerintah desa, BPD, LPMD), aktor internal birokrasi pembuat kebijakan public/ Political Apoinment Official (dalam hal ini perangkat desa) berada ditengah - tengah antara elit dan masyarakat, Masyarakat/ Public dimana masyarakat berada pada tingkat paling bawah. Berdasahkan hasil penelitian, terdapat unsur-unsur yang terlibat dalam membuat formulasi kebijakan pembangunan di Desa dermaji yaitu: Lembaga Pemerintahan Desa dan masarakat seperti yang disampaikan oleh Ketua Urusan Perencanaan Desa Dermaji bahwa yang terlibat dalam proses perencanaan pembangunan adalah Pemerintah Desa, BPD, LPMD, RT/RW dan seluruh komponen 
masyarakat. Artinya, dalam proses formulasi kebijakan pembangunan di Desa Dermaji berupaya membangun pola dimana struktur birokrasi pemerintah desa memberikan peluang adanya keterlibtan dari berbagai stakeholders.

Hal ini menunjukan dalam proses pembuatan perencanaan kebijakan pembangunan di Desa dermaji diikuti oleh Elits, political apoinment official dan public. Dalam suatu pendekatan model elit berupaya membangun kekuatan dalam pengambilan keputusan yang berusaha membangun alur komunikasi antara pemerintah desa dan masyarakat (Sebola, 2016; Suwitri, 2014). Dalam menetukan pilihan alterntif dalam formulasi kebijakan pembangunan di Desa Dermaji, agenda kebijakan yang bersifat strategis dan inovatif muncul dari pemerintahan desa khususnya Kepala Desa Dermaji. Gagasan atau ide-ide yang akan dijadikan perencanaan program pembangunan didapatkan melalui usulan-usulan masyarakat dan hasil penelitian yang dilakukan langsung terhadap masyarakat didasarkan pada kebutuhan dan analisis seluruh potensi yang ada dan telah di bahas secara khusus oleh tim 11 dan tim musawarah khusus. Pemerintah Desa berusaha meyakinkan masyarakat terkait pilihan skala prioritas yang dipilih untuk dijakan program-program yang akan dilaksanakan agar masyarakat memahami melalui forum Musrenbangdes, Sistem Informasi Desa dan forum-forum pertemuan yang ada di Desa Dermaji. Terkait sosialisasi rencana program pembangunan apabila ada masyarakat yang berpendapat, ada usulan dari maysrakat yang belum dimasukkan kedalam skala prioritas maka akan dicatat kemudian dibahas di tim TPKD untuk di pertimbangkan urgensinya bisa atau tidak dimasukkan kedalam skala prioritas. Hal ini menunjukan bahwasanya elit berusaha mempengarusi masyarakat dalam pengambilan keputusan terkait skala prioritas program pembangunan. Penentuan keputusan masih tetap dilakukan oleh elit, walaupun pada prosesnya melibatkan masyarakat namun hanya dalam bentuk penjaringan aspirasi pembangunan saja. Usaha ini dilakukan agar program pembanguna yang sudah ditetapkan nantinya akan mendapatkan dukungan dari masyarakat. Artinya dalam memandang kebijakan harus secara komperhensif, dimana dalam penentuan kebijakan harus dilakukan sesuai dengan kebutuhan. Saat ini Pemerintah Desa Dermaji dalam melakukan kebijakan pembangunan bersifat social collaborative action (berupaya membangun kerjasama dengan berbagai elemen baik dari usur masyarakat dan unsur pemerintah desa yang saling bersinergi). Selian itu, adanya unsur kekuatan kepemimpinan dalam penentuan kebijakan dan adanya media aspirasi masyarakat dalam menyampaikan usulan melalui forum yang difasilitasi oleh Pemerintah Desa Dermaji. Hal inilah yang menjadi strategi yang dijalankan oleh Desa Dermaji, sehingga secara bertahap Desa Dermaji mengalami kemajuan baik dibidang pembangunan, bidang pemberdayaan, dan pembangunan ekonomi. Artinya, dapat diketahui dalam proses formulasi kebijakan pembanguna Desa Dermaji berupaya memadukan pendekatan masyawarah sebagai acuan aspirasi masyarakat terhadap semua bentuk usulan 
rencana pembangunan. Sedangkan pendekatan elit digunakan sebagai sarana dalam membangun komunikasi antara unsur pemerintah desa dan masyarakat dalam pengambilan kebijakan.

\section{KESIMPULAN}

Perumusan kebijakan menjadi salah tahapan yang sangat penting untuk menentukan berbagai solusi dan alternatif melalui proses yang dinamis. Proses perumusan kebijakan pembangunan Desa Dermaji meliputi beberapa aspek yang penting serta menjadi faktor pendukung keberhasilan pembangunan Desa Dermaji. Tahapan perumusan kebijakan yang dilakukan meliputi aspek identifikasi masalah pemataan potensi desa, pemataan kondis sosial ekonomi masyarakat. Adanya unsur konseptualisasi masalah yang dilakukan dengan adanya upaya membangun kesamaan presepsi antara pemerintah desa dan masyarakat yang dilakukan saat ini oleh pemerintah Desa Dermaji mampu membuka peluang bagi masyarakat dalam turut serta memberikan arahan dan kontrol dalam pelaksanaan pembangunan. Penetuan opsi dan alternatif pembangunan dilakukan dengan adanya pelibatan berbagai unsur dan stakeholder, serta hasil muswarah dalam penentuan alternatif kebijakan pembangunan desa melalui fasilitasi masyarakat dalam memberikan berbagai usulan dan aspirasi yang dibuat dalam rancangan rod map pembangunan Desa Dermaji. Ketiga aspke tersebut menjadi landsan Pemerintah Desa Dermaji dalam melakukan tahapan pembangunan. Selain aspek tersebut adanya faktor kepemimpinan dari kepal desa sehingga mampu membawa desa dermaji terus berupaya memningkatkan proses pembangunan yang ditukan sebagai landasan utama dalam peningkatan pemberdayaan masyarakat dan peningkatan ekonomi masyarakat secara berkelanjutan. Dengan adanya peran serta masyarakat melalui pertisipasi yang berkelnjutan maka diharapkan perumusan kebijakan yang saat ini dilakukan oleh Pemerintah Desa Dermaji menjadi strategi yang cukup efektif. Hal ini bertujuan agar proses kebijakan pembangunan desa tetap mengutamakan asas pertisipasi dan keberlanjutan dengan nilai-nilai kerjasama dan semangat gotong royong.

\section{DAFTAR PUSTAKA}

Abady, A. P. (2013). Perencanaan Partisipatif Dalam Pembangunan Daerah. Otoritas : Jurnal Ilmu Pemerintahan, 3(1). https://doi.org/10.26618/ojip1.55

Anderson, James E. 2003. Public Policy Making: An Introduction. Fifth Edition,. Boston: Houghton Mifflin Company

Abdul Rahman, Martoyo, E. (2016). Formulasi Kebijakan Penyusunan Rencana Pembangunan Jangka Menengah Desa (Rpjmdes) Di Desa Sungai Ambawang Kuala Kecamatan Sungai Ambawang Kabupaten Kubu Raya. Doctoral Dissertation, Universitas Tanjungpura Pontianak. 
Ashworth, R. E., McDermott, A. M., \& Currie, G. (2019). Theorizing from Qualitative Research in Public Administration: Plurality through a Combination of Rigor and Richness. Journal of Public Administration Research and Theory.

B.Miles, M., Huberman, A. M., \& Saldana, J. (2014). Qualitative Data Analysis - Matthew B. Miles, A. Michael Huberman, Johnny Saldaña - Google Books. In Sage Publications.

Birkland, Thomas A. 2007. An Introduction to the Policy Process: Theories, Concepts, and Models of Public Policy Making. New York: M. E. Sharpe

Baekgaard, M., Mortensen, P. B., \& Seeberg, H. B. (2018). The bureaucracy and the policy agenda. Journal of Public Administration Research and Theory, 28(2), 239-253.

Brower, R. S., Abolafia, M. Y., \& Carr, J. B. (2000). On improving qualitative methods in public administration research. Administration and Society, 32(4).

Buckley, N., \& Tucker, J. A. (2019). Staring at the West through Kremlin-tinted glasses: Russian mass and elite divergence in attitudes toward the United States, European Union, and Ukraine before and after Crimea. Post-Soviet Affairs, 35(5-6).

Creswell, J. W., \& Creswell, J. D. (2018a). Research Design: Qualitative, Quantitative, and Mixed Methods Approaches - John W. Creswell, J. David Creswell - Google Books. In SAGE Publications, Inc.

Creswell, J. W., \& Creswell, J. D. (2018b). Research Design: Qualitative, Quantitative, and Mixed Methods Approaches - John W. Creswell, J. David Creswell - Google Books. In SAGE Publications, Inc.

Fandaru, R. R. A. (2016). New Design of Raskin Program (Analysis Implementation RASDA in Kulonprogo Regency). JKAP (Jurnal Kebijakan Dan Administrasi Publik), 20(1), 68.

Goodnow, Frank J. 1900. Politics and Administration. Dalam Shafritz, Jay M. \& Albert C. Hyde. 2017. Classics of Public Administration. Belmont. Wadsworth Publishing Company. p. 48 55.

Hektner, J., Schmidt, J., \& Csikszentmihalyi, M. (2012). Experience Sampling Method. In Experience Sampling Method. https://doi.org/10.4135/9781412984201

Howlett, Michael \& Ishani Mukherejee. 2017. "Policy Design: From Tools to Patches". Canadian Public Administration. Vol. 60 (1): 140-144.

Howlett, Michael \& M. Ramesh. 2003. Studying Public Policy: Policy Cycles and Policy Subsystems. Oxford: Oxford University Press.

Henry, Nicholas. 1975. "Paradigms of Public Administration" Jurnal Public Administration Review, Vol. 35, No. 4 (Jul - Aug., 1975): 378- 386.

Kadji, Y. (2015). Formulasi dan implementasi kebijakan publik, kepemimpinan danperilaku birokrasi dalam fakta realitas. (Vol. 66).

Kettl, Donald. 2000. "Public Administration at the Millennium: The State of the Field". Journal of Public Administration Research and Theory, Vol. 10, Issue 1: 7-34.

Lim, S., Berry, F. S., \& Lee, K. H. (2016). Stakeholders in the Same Bed with Different Dreams: 
Semantic Network Analysis of Issue Interpretation in Risk Policy Related to Mad Cow Disease. Journal of Public Administration Research and Theory, 26(1), 79-93.

Morgan, D. L. (2017). Integrating Qualitative and Quantitative Methods: A Pragmatic Approach. In Integrating Qualitative and Quantitative Methods: A Pragmatic Approach.

Nathan, A. J., \& Scobell, A. (2012). Experience sampling method:Measuring the quality of everyday life. In Foreign Affairs (Vol. 91, Issue 5)

Nugroho, R. (2008). Public Policy: Teori Kebijakan, Analisis Kebijakan, Proses Kebijakan, Perumusan, Implementasi, Evaluasi, Revisi, Risk Management dalam Kebijakan Publik, Kebijakan sebagai Fifth Estate, Metode Penelitian Kebijakan. In Jakarta: Elex Media Komputindo.

O'Connor, K. (2013). Belfast revisited: Everyday policymaking in a contested environment. Irish Political Studies, 28(1).

Ospina, S. M., Esteve, M., \& Lee, S. (2018a). Assessing Qualitative Studies in Public Administration Research. Public Administration Review, 78(4).

Ospina, S. M., Esteve, M., \& Lee, S. (2018b). Assessing Qualitative Studies in Public Administration Research. Public Administration Review, 78(4), 593-605.

Politik, R. J. (2017). Politik dan Kebijakan (Publik). Jurnal Politik, 3(1).

Rahman, A., Desa, P., Kebijakan, F., Perencanaan, P., \& Jangka, P. (2014). Formulasi Kebijakan Penyusunan Rencana Pembangunan Jangka Menengah ( Rpjm ) Desa Sungai Ambawang Kuala Kecamatan Sungai Ambawang Kabupaten Kubu Raya.

Rothstein, J., \& Valletta, R. G. (2017). Scraping by: Income and Program Participation After the Loss of Extended Unemployment Benefits. Journal of Policy Analysis and Management, $36(4), 880-908$.

Sabatier, P. (2019). Theories of the Policy Process. In Theories of the Policy Process.

Sebola, M. P. (2016). Public Participation in South Africa's Policy Decision-Making Process: The Mass and the Elite Choices. Central European Public Administration Review, 14(1), 55-73. https://doi.org/10.17573/ipar.2016.1.03

Shiddike, M. O., \& Rahman, A. A. (2020). Case Study Method in Human Resource Development: Reviewing the Research Literature. International Business Research, 13(4), 113.

Simonet, D. (2018). Reforming the French health-care system: the quest for accountability. International Review of Administrative Sciences, 84(3), 503-519. https://doi.org/10.1177/0020852316648226

Suwitri, S. (2014). Konsep Dasar Kebijakan Publik MODUL 1. Analisis Kebijakan Publik, 2. https://doi.org/http://dx.doi.org/10.1016/j.atmosenv.2007.12.054

Tashakkori, A., \& Newman, I. (2010). Mixed Methods: Integrating Quantitative and Qualitative Data Collection and Analysis While Studying Patient-Centered Medical Home Models. In International Encyclopedia of Education (Issue 301, pp. 514-520).

Tramontin, V., Loggia, C., \& Trois, C. (2012). Strategies for stustainable building design and 
retrofit in developing countries. New goals for green buildings in South Africa. In Journal of Construction (Vol. 5, Issue 1).

Vigoda-Gadot, Eran. 2003. Managing Collaboration in Public Administration: The Promise of Alliance Among Governance, Citizens, and Businesses. Westport: Praeger.

Waldo, Dwight. 2013. "An Eclectic View of Public Administration”. Dalam Bryan R. Fry \& Jos C.N. Raadschelders. Mastering Public Administration: From Max Weber to Dwight Waldo. Thousand Oaks, California: Sage Press. p. 387 - 416

Wisdom, J., \& Creswell, J. W. (2013). Integrating quantitative and qualitative data collection and analysis while studying patient-centered medical home models. Agency for Healthcare Reseach and Quality,

$\mathrm{Wu}$, Ramesj, Howlett, F. (2010). Public managers and the policy process. In A Public Policy Primer (pp. 1-28). 